\title{
Economic Status of Community Interest in Membership of BPJS Health in Duampanua District, Pinrang Regency
}

\author{
Sri Nurul Kur'aini ${ }^{1}$, Amran Razak $^{1 *}$, Anwar Daud $^{2}$, Anwar Mallngi $^{2}$ \\ ${ }^{1}$ Department of Health Administration and Policy, Public Health of Faculty, Hasanuddin University, Makassar, Indonesia; \\ ${ }^{2}$ Department of Environmental Health, Public Health of Faculty, Hasanuddin University, Makassar, Indonesia
}

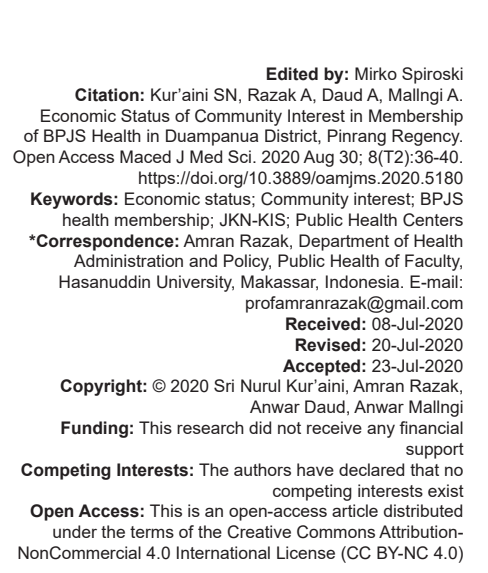

Abstract

BACKGROUND: Starting from 2017 until 2019, the number of patient visiting public health centers Lampa is always more than the number of patient visits BPJS, it indicates that the public interest in District Duampanua, Pinrang Regency on BPJS Health membership is still lacking.

AIM: This study aimed to determine the effect of economic status on community interest in BPJS health membership. METOHDS: This study used a quantitative research with cross-sectional study approach. The location of this research was in the District Duampanua, Pinrang Regency. The population in this study is the community in Duampanua District Pinrang Regency with 51.593 people. The sampling technique in this study used a purposive sampling technique with 100 sample size. Data analysis performed was univariate and bivariate with Chi-square test. RESULTS: The results showed that there are influence of economic status variables $(p=0.016)$ to community interest in BPJS Health membership in Duampanua District, Pinrang Regency. The conclusion of this study is that there is an influence of economic status on community interest in BPJS Health membership because the higher the economic status of the community, the higher their interest in BPJS Health membership

CONCLUSION: It is expected that stakeholders in each village in the Duampanua District can find out the income of the community by conducting data collection evenly as proof of their worthiness of being members of JKN-KIS participants.

\section{Introduction}

Since 2014, the Indonesian government has made a commitment to provide health insurance coverage for all people through a public health insurance system, compulsory namely the issuance of a Law on the Social Security Organizing Agency (BPJS). BPJS implementation is an effort to increase insurance coverage for services health in Indonesia [1].

One of the missions of the Health Social Security Organizing Agency is to expand JKN membership to include all Indonesian citizens no later than January 1, 2019 through increasing partnerships with all stakeholders and encouraging participation community and increasing membership compliance. In addition, the BPJS Health target is that the entire population of Indonesia (which in 2019 is estimated to be around 257.7 million people) gets health insurance through the BPJS Health [2]. Efforts to encourage participation public to achieve Universal Health Coverage (UHC) means that all Indonesian citizens must be registered as JKN participants, it is important for all sectors to support and make various efforts so that all Indonesian citizens are registered as JKN participants through proof of JKN card ownership [3].
UHC has become a major goal of health reform in many countries. Funding is the main driver of UHC and many countries including low- and middle-income countries are looking for better options to modify their health financing systems to support the realization of UHC [4].

Starting from 2017 until 2019, the number of patients visiting public health centers Lampa is always more than the number of patient visits BPJS, it indicates that the public interest in the District Duampanua, Pinrang Regency on BPJS Health membership is still lacking. During the 5 years of the JKN program, not all Indonesians have been protected by JKN. This can be seen from the data on the number of BPJS Health participants. Nationally, the number of BPJS Health participants until June 1, 2019 totaling 222,002,996 people $(82.53 \%)$ of Indonesia's population has participated in national health insurance from a total population of around 269,536,482 people. Membership coverage for South Sulawesi Province until 2019 was $9,400,000$ people registered as participants of the BPJS Health. For Pinrang Regency, the number of BPJS participants until 2019 was 217,432. The phenomenon is seen in the field, BPJS Health is not optimal in increasing the number of participants JKN in Duampanua District, Pinrang Regency [5]. 
There are various things that can influence the community to want to become JKN participants, both in terms of the characteristics and perceptions of the community of JKN, especially those who have not been participants in the national health insurance before. Based on research conducted by Endartiwi, it was stated that the factors affecting the community were still reluctant to register to become independent BPJS participants due to economic factors, lack of information, and indeed they were not yet interested in registering to become BPJS participants independently [6].

Other research conducted by Pebrian shows that the problem that causes the low interest of the community to register for $\mathrm{JKN}$ is because there are still many people who do not understand the rules and procedures for getting services from BPJS Health. The public does not understand BPJS Health rules and procedures. The lack of public knowledge is caused by the lack of direct socialization to the public about the Health BPJS so that many people in Siak Regency are still not registered [7].

Research by Adewole et al. states that poor health insurance performance in Nigeria is largely due to low public awareness of the importance of being a participant in health insurance. Factors such as age, marital status, education, and residence are some of the demographic factors that influence people's awareness to register for health insurance participants [8].

The results of initial observations made in Duampanua District can be seen that there are still many people who have not yet become BPJS health participants, especially BPJS participants it is independent because the community income is not enough, while they have many other needs to be fulfilled such as children's education costs, daily needs, and so forth. In addition, the public thought that if they become independent BPJS participants, it is as if they are throwing money away for nothing because their money is not returned like insurance other. The purpose of this study was to determine the factors that influence interest community in BPJS Health membership in Duampanua District, Pinrang Regency.

\section{Materials and Methods}

This study was conducted in Duampanua District, Pinrang Regency. This type of research used in this research is quantitative research with a crosssectional study approach.

Collection is done by distributing questionnaires to respondents that contain a list of questions. Secondary data were obtained from the Puskesmas, namely, from the profile Community Health Centers, the
Population and Civil Registry Office, and the Insurance Administering Agency Health of the Pinrang Regency.

Analysis used in this study is univariate and bivariate. Univariate analysis is an analysis that reveals the personal data respondents, obtained from respondents answers through a questionnaire. This bivariate analysis was conducted to find out each independent variable with the dependent variable of the study with cross tabulation and test Chi-square.

\section{Results}

Table 1 shows the characteristics of respondents based on age, sex, last education, occupation, and income per month. Based on the age characteristics, the highest number of respondents was in the age group of 41-50 years as many as 46 people $(46.0 \%)$, while the number of respondents was the least in the age group of 51-60 years which was as many as 5 people (5.0\%). Based on gender, the highest number of respondents was male, namely 53 people $(53.0 \%)$, while sex female was 47 people $(47.0 \%)$. Based on the recent education, the respondents were most the high school/equivalent level of 44 people (44.0\%), while the fewest respondents did not complete elementary school, namely as many as 2 people $(2.0 \%)$. Based on the work, the most number of respondents were housewives (IRT) as many as 22 people (22.0\%), while the fewest respondents were students/college students, as many as 7 people $(7.0 \%)$. Based on income per month, the highest number of respondents is $<R p$. $1,500,000$, which is 70 people $(70.0 \%)$, while the lowest number of respondents is $\mathrm{Rp} 1,500,000-2,500,000$, which is 8 people $(8.0 \%)$

Table 1: Characteristics of respondents in Duampanua District, Pinrang Regency in 2019

\begin{tabular}{llll}
\hline Characteristics of & Category & \multicolumn{2}{l}{ Frequency } \\
\cline { 3 - 4 } respondents & & 27 & $\%$ \\
\hline Age & $19-29$ & 22 & 27.0 \\
& $30-40$ & 46 & 46.0 \\
\multirow{4}{*}{ Gender } & $41-50$ & 5 & 5.0 \\
& $51-60$ & 53 & 53.0 \\
Last education & Male & 47 & 47.0 \\
& Female & 2 & 2.0 \\
& Not graduated from elementary school & 12 & 12.0 \\
& Elementary school/equivalent & 20 & 20.0 \\
& Junior high school/equivalent & 44 & 44.0 \\
Occupation & High school/equivalent & 22 & 22.0 \\
& University & 7 & \\
& Student/college student & 8 & 8.0 \\
& Civil servants/military/police & 14 & 14.0 \\
& Entrepreneurs & 17 & 17.0 \\
& Laborers & 22 & 22.0 \\
& Housewife (IRT) & 18 & 18.0 \\
& Farmers & 12 & 12.0 \\
& Private employees & 2 & 2.0 \\
Income per month & Others & 70 & 70.0 \\
& <Rp 1.500.000 & 8 & 8.0 \\
& Rp 1.500.000 - 2.500.000 & 22 & 22.0 \\
\hline
\end{tabular}

Table 2 shows that of 100 respondents in Duampanua District, Pinrang Regency from the economic status, there were 69 people (69.0\%) who 
Table 2: Univariate analysis of respondents distribution based on economic status variables in Duampanua District, Pinrang Regency in 2019

\begin{tabular}{lll}
\hline Variables & $\mathrm{n}$ & $\%$ \\
\hline Economic status & & \\
High & 31 & 31.0 \\
Low & 69 & 69.0 \\
\hline
\end{tabular}

stated that the economic status was high and 31 people $(31.0 \%)$ stated that the economic status was low.

Table 3 shows that of 100 respondents classified as high economic status and interest high, 19 people $(61.3 \%)$ and those who have high economic status and low interest as many as 12 people (38.7\%). While respondents classified as low economic status and high interest were 23 people $(33.3 \%)$ and those classified as low economic status and low interest were 46 people $(66.7 \%)$. Statistical test results obtained the value of $p=0.016$ because the value of $p<\alpha=0.016$ $<0.05$ then $\mathrm{Ho}$ is rejected, this means that there is an influence between economic status variables with community interest in BPJS Health membership in Duampanua District, Pinrang Regency.

Table 3: Bivariate analysis of the effect of economic status on community interest in BPJS health participation in Duampanua district, Pinrang Regency in 2019

\begin{tabular}{|c|c|c|c|c|c|c|c|}
\hline \multirow[t]{3}{*}{ Variable } & \multicolumn{4}{|c|}{ Interest } & \multirow{2}{*}{\multicolumn{2}{|c|}{ Total }} & \multirow{3}{*}{$\begin{array}{l}\text { Statistical } \\
\text { test results }\end{array}$} \\
\hline & \multicolumn{2}{|c|}{ High } & \multicolumn{2}{|c|}{ Low } & & & \\
\hline & $\mathrm{n}$ & $\%$ & $\mathrm{n}$ & $\%$ & $\mathrm{n}$ & $\%$ & \\
\hline \multicolumn{8}{|c|}{ Economic status } \\
\hline High & 19 & 61.3 & 12 & 38.7 & 31 & 100.0 & $p=0.016$ \\
\hline Low & 23 & 33.3 & 46 & 66.7 & 69 & 100.0 & \\
\hline
\end{tabular}

\section{Discussion}

The results of the study indicate that the economic status variable has significant influence on community interest in BPJS Health membership in Duampanua District, Pinrang Regency.

The higher the economic status of the community, the higher their interest in BPJS Health membership is.

Economic status is related to income family, with a good enough income, in fulfilling the needs of life and health, they will be more secure and the funds for health costs they have prepared. While people who have low incomes are very afraid of the cost of treatment because they do not have enough money and the high cost of drugs that must be purchased [9]. The higher one's economic status, the higher the willingness to pay and the willingness to pay for people in urban areas is higher than semi-urban areas, and rural areas [10].

The results of this study are in line with the results of research conducted by Johariyah [11] which states that there is a significant relationship between economic status and independent BPJS participation in obstetric patients in Cilacap Hospital 2016. The higher one's income, the higher public awareness in insurance is. Likewise research conducted by Kuwawenaruwa et al. [12] which states that the willingness of people in Tanzania to become participants in health insurance is influenced by economic factors. The economic factor in question is family income with status low economic. People with low economic status tend to be unwilling to join health insurance so they are considered for cross subsidies and fee waivers for them. Other research conducted by Lofgren et al. [13] in Vietnam states that a person's income to meet the needs for health care is a significant determinant that can influence households to be willing to become participants of health insurance.

The results of this study are also in line with the results of research conducted by Untari and Putri [14] stating that the relationship between the family's socioeconomic level and BPJS ownership shows that there is a significant relationship between the socioeconomic level of the family and BPJS ownership $(p=0.000<0.05)$ and the correlation is 0.471 . The data show that BPJS has the majority of families with low socioeconomic levels, including $\mathrm{PBI}$, so they do not pay fees but are funded by the government. In the middle economic community that has BPJS only 52 respondents of 65 respondents $(80 \%)$, whereas in families with socioeconomic level upper only 12 respondents of 48 respondents (25\%). Hence, it can be concluded that the level of public awareness there is still low to participate in BPJS membership.

Another study conducted by Onwujekwe et al. [10] states that there is a significant relationship between economic status with the willingness of people to become participants in the Community-based Health Insurance (CBHI) where economic status is a factor that greatly affects the willingness to pay the respondent and membership $\mathrm{CBHI}$. In general, $<40 \%$ of respondents are willing to pay $\mathrm{CBHI}$ contributions for themselves or their members family. The lowest proportion of people's willingness to pay occurs in respondents living in rural areas, which is $<7 \%$.

However, the results of this study are not in line with the results of research conducted by Pangestika et al. [15] which states that the results of the test Chisquare show that no there is relationship between income and BPJS Health Mandiri membership in the sector informal. The value of $p=0.050 \geq 0.05$ then $\mathrm{Ha}$ is rejected, so there is no relationship between income and BPJS Health Mandiri membership in the informal sector.

Based on the interview results from the questionnaire questions, there are still some indicators on economic status variables that indicate community interest in membership BPJS Health such as the question item "Your income influences participation insurance" where people with low income agree to the item as much as $58 \%$ which means income or income is a factor that influences community interest in participating in BPJS health participants. 
People with low incomes tend to be unwilling to become BPJS health participants because the income they earn in a month is only enough to meet their daily needs as in the item "Following BPJS health does not interfere with my income results to meet daily needs" where as many as $54 \%$ which states that they disagree, which means that following BPJS Health disrupts their income to meet their daily needs. Whereas for people who have a high income, the community prefers to be a public patient because according to the community in Duampanua District, the service they get is almost the same as the service obtained by BPJS Health participants, the difference is that general patients only pay when they are treated compared to independent BPJS participants who must pay per month according to the class and this is the reason they are not interested in becoming BPJS Health participants.

The problem in the field is that public awareness of participation in BPJS health is still low. In addition, the community still considers the costs for BPJS, especially the Mandiri BPJS expensive, with the average income of the Duampanua District being <Rp. 1,500,000 per month with the majority of jobs being farmers, so this is not a big number to share in meeting their daily needs. Of course, this is one of the community's considerations in determining participation in the BPJS program, especially the independent BPJS.

Economic status is related to family income, with an enough income good, in fulfilling the needs of life and health, they will be more secure and the funds for health costs they have prepared. While people who have incomes low are very afraid of the cost of treatment because they do not have enough money and the high cost of drugs that must be purchased [9]. The higher economic status one's, the higher the willingness to pay and the willingness to pay for people in urban areas is higher than semi-urban areas, and rural areas [10]. High income residents, with their own awareness, will use health insurance for themselves and their families [16].

A measure of one's wealth income will affect insurance participation. They are willing to pay more for health insurance for those who have more income. Moreover, vice versa for those with little income certainly will affect the consideration for having insurance [17].

According to Dalaba et al. (2012) states that registration is higher in the group high income in accordance with consumer theory which considers health insurance as an item with positive elasticity of demand. Likewise, according to Sarpong et al. [18] states that health insurance registration is generally higher in people from higher socioeconomic groups.

\section{Recommendation}

It is expected that BPJS Health agencies conduct socialization activities in Duampanua District regarding the importance of participating in the current program BPJS health. For stakeholders in Duampanua District both in villages and villages to find out the income of their citizens by collecting data evenly and visiting the residents homes as proof of their appropriateness to be given assistance National Health Insurance-Healthy Indonesian Card (JKN-KIS).

\section{Conclusion}

It is expected that stakeholders in each village in the Duampanua District can find out the income of the community by conducting data collection evenly as proof of their worthiness of being members of JKN-KIS participants.

\section{References}

1. Ngafiyah N. Akses Masyarakat Miskin Terhadap Pelayanan Kesehatan Program BPJS Kesehatan Di Kelurahan Bumirejo Kabupaten Kebumen, Tesis. Semarang: Universitas Negeri Semarang; 2015. https://doi.org/10.35451/jkg.v1i2.115

2. Kemenkes RI. Peta Jalan Menuju Jaminan Kesehatan Nasiona 2012-2019. Jakarta: Kementerian Kesehatan Republik Indonesia; 2012.

3. Kurniawati WR. Identifikasi penyebab rendahnya kepesertaan JKN pada pekerja sektor informal di kawasan pedesaan. J Adm Kesehatan Indones. 2018;6(1):33-9. https://doi.org/10.20473/ jaki.v6i1.2018.33-39

4. Korankye AA. Challenges of financing health care in ghana: The case of national health insurance scheme (NHIS). Int J Asian Soc Sci. 2013;3(2):511-22

5. Badan Penyelenggara Jaminan Sosial. Data Jumlah Peserta BPJS Kesehatan Kabupaten Pinrang Tahun 2018. Pinrang: Badan Penyelenggara Jaminan Sosial; 2019. https://doi. org/10.31219/osf.io/m5pvh

6. Endartiwi SS. Persepsi masyarakat terhadap kemauan untuk mendaftar menjadi peserta mandiri jaminan kesehatan nasional (JKN). J Health Stud. 2018;3(2):87-98. https://doi.org/10.31101/ jhes.381

7. Pebrian A. Strategi badan penyelenggara jaminan sosial (BPJS) kesehatan dalam meningkatkan jumlah peserta jaminan kesehatan nasional (JKN) di kabupaten siak. J Adm Public. 2019;6(1):1-13. https://doi.org/10.30996/jpap.v3i1.1240

8. Adewole D, Bolarinwa O, Dairo M. National health insurance scheme and universal health coverage among formal sector employees in llorin, Nigeria: Has any progress been made. Int J Trop Dis Health. 2016;18(4):1-10. https://doi.org/10.9734/ ijtdh/2016/27777

9. Notoatmodjo S. Pendidikan dan Perilaku Kesehatan. Jakarta: Rineka Cipta; 2003.

10. Onwujekwe OE, Uzochukwu BS, Obikeze EN, Okoronkwo I, Ochonma OG, Onoka CA, et al. Investigating determinants of out-of-pocket spending and strategies for coping with payments for healthcare in Southeast Nigeria. BMC Health Serv Res. 2010;10(1):67-76. https://doi.org/10.1186/1472-6963-10-67

11. Johariyah J. Analisis keikutsertaan BPJS Mandiri berdasarkan status ekonomi, sikap, dan persepsi atas mutu layanan. J IImiah 
Kebidanan. 2016;7(2):20-33.

12. Kuwawenaruwa A, Macha J, Borghi J. Willingness to pay for voluntary health insurance in Tanzania. East Afr Med J. 2011;88(2):54-64.

PMid:24968592

13. Lofgren C, Thanh NX, Chuc NT, Emmelin A, Lindholm L. People's willingness to pay for health insurance in rural Vietnam. Cost Eff Resour Alloc. 2008;6(1):1-16. https://doi. org/10.1186/1478-7547-6-16

PMid:18691440

14. Untari I, Putri AH. Hubungan antara tingkat sosial ekonomi keluarga dengan kepemilikan BPJS (badan penyelenggara jaminan sosial). Profesi (Profesional Islam): Media Publikasi Penelitian, 2015;13(1):30-37. https://doi.org/10.26576/ profesi. 150

15. Pangestika VF, Jati SP, Sriatmi A. Faktor-faktor yang berhubungan dengan kepesertaan sektor informal dalam BPJS kesehatan mandiri di kelurahan poncol, kecamatan pekalongan timur, kota Pekalongan. J Kesehatan Masyarakat. 2017;5(3):3948. https://doi.org/10.14710/jkli.16.1.22-28

16. Sari $B$, Idris $H$. Determinant of independent national health insurance ownership in Indonesia. Malays J Public Health Med. 2019;19(2):109-15. https://doi.org/10.37268/mjphm/vol.19/no.2/ art.177

17. Dalaba M, Akweongo $\mathrm{P}$, Aborigo R, Ataguba J. To insure or not to insure: The influence of insurance status on health seeking behaviour in the Kassena-Nankana district of Ghana. Afr J Health Sci. 2012;21(3-4):161-73.

18. SarpongN, LoagW, FobilJ, MeyerCG,Adu-SarkodieY,MayJ, etal National health insurance coverage and socio-economic status in a rural district of Ghana. Trop Med Int Health. 2010;15(2):1917. https://doi.org/10.1111/j.1365-3156.2009.02439.x PMid:19961565 